\title{
Ammonia Removal Using Biotrickling Filters: Part B: Determination of the Nitrogen Accumulation in the Scrubbing Liquid at a Livestock Facility Using Electrical Conductivity Measurement
}

\author{
Éric Dumont ${ }^{1, *}$, , Solène Lagadec ${ }^{2}$, Nadine Guingand ${ }^{3}$, Laurence Loyon ${ }^{4}$, Abdeltif Amrane ${ }^{5}$ \\ and Annabelle Couvert ${ }^{5}$ \\ UMR 6144, Oniris, GEPEA, Université de Nantes, IMT Atlantique, 44307 Nantes, France \\ Chambre d'Agriculture de Bretagne, 35042 Rennes, France; solene.lagadec@bretagne.chambagri.fr \\ IFIP Institut du Porc, 35651 Le Rheu, France; nadine.guingand@ifip.asso.fr \\ INRAE, 35044 Rennes, France; laurence.loyon@irstea.fr \\ ISCR-UMR6226, CNRS, ENSCR, Université de Rennes, 35000 Rennes, France; \\ abdeltif.amrane@univ-rennes1.fr (A.A.); annabelle.couvert@ensc-rennes.fr (A.C.) \\ * Correspondence: eric.dumont@imt-atlantique.fr; Tel.: +33-025-185-8266
}

Received: 1 April 2020; Accepted: 7 August 2020; Published: 18 August 2020

\begin{abstract}
It was demonstrated that the daily monitoring of electrical conductivity (EC) of scrubbing water can easily be used to determine the performance of biotrickling filters treating ammonia $\left(\mathrm{NH}_{3}\right)$ emissions, generated by livestock facilities. Two different measurement campaigns were carried out on a pilot-scale biotrickling filter installed at a pig facility. Different phases of the operation were observed for each campaign, in accordance with EC values. For EC ranges of between 5 and $40 \mathrm{mS} \mathrm{cm}^{-1}$, performance was similar for both campaigns, indicating that the nitrogen accumulated in water $(\varphi)$ was controlled by the operating conditions and biotrickling filter design $\left(\varphi=205 \mathrm{~g}_{\mathrm{N}}\right.$ day $^{-1}$ corresponding to $1.71 \mathrm{mS} \mathrm{cm}^{-1} \mathrm{day}^{-1}$ ). Due to the correlation established in Part A of this study, the performance of the biotrickling filter can be directly expressed as $\mathrm{g}_{\mathrm{N}} \mathrm{h}^{-1} \mathrm{~m}^{-3}$ packing material without gas-phase monitoring. Thus, for an Empty Bed Residence Time of $1 \mathrm{~s}$, the nitrogen accumulation capacity of the biotrickling filter was $24 \mathrm{~g}_{\mathrm{N}} \mathrm{h}^{-1} \mathrm{~m}^{-3}$ packing material. For higher EC values, the ammonia mass transfer slowed down and stopped with EC at around 50-60 mS cm$~^{-1}$ (campaign \#1) and $70 \mathrm{mS} \mathrm{cm}^{-1}$ (campaign \#2). It was evidenced that the mass transfer stopped due to ammonia mass transfer limitation controlled by the driving force, although biomass inhibition can occur at these levels of nitrogen concentration in the scrubbing liquid. EC monitoring can also be used to assess the ratio of nitrogen accumulated in water $\varphi$ and amount of ammonia entering the system $\varphi_{\max }$. Thus $\varphi / \varphi_{\max }$ ratios of $41 \%$ and $27 \%$ were recorded for campaign \#1 and \#2 respectively.
\end{abstract}

Keywords: ammonia; absorption; mass transfer; air treatment; biofiltration; electrical conductivity

\section{Introduction}

Ammonia $\left(\mathrm{NH}_{3}\right)$ emissions from livestock facilities are the target of many think tanks in several countries [1-3]. Indeed, intensive farming has become the source of harmful effects on ecosystems, olfactory nuisances and gaseous pollution for neighborhoods [4]. Most of the time, ammonia is treated in conventional biotrickling filters which are considered an economical technique [5-7]. In biotrickling filters, the gaseous phase is sprayed by a scrubbing liquid (water) that continuously recirculates using a storage tank. As a result, the continuous ammonia absorption into the scrubbing liquid leads to the accumulation of large amounts of nitrogen ions in the water (mainly ammonium $\mathrm{NH}_{4}{ }^{+}$, nitrite 
$\mathrm{NO}_{2}{ }^{-}$and nitrate $\mathrm{NO}_{3}{ }^{-}$), which can limit the ammonia transfer rate. To avoid this accumulation, part of the recirculating water can be discharged and replaced with fresh water. Nevertheless, this operation is not always carried out at livestock facilities, so that the ability of the biotrickling filters to remove ammonia are often questioned. The determination of the performance of these apparatus is difficult to assess at an industrial scale. Removal efficiency (RE) of around $70-80 \%$ is expected, but values of between $10 \%$ and $99 \%$ are reported in the literature [8]. The large disparities between RE values may be due to the hydrodynamic conditions applied in biotrickling filters, which are different between one device and another. The possible inhibition of the biomass is fixed on the packing material and present in the scrubbing liquid, i.e., ammonia oxidizing bacteria (AOB) and nitrite oxidizing bacteria (NOB). Therefore, there is a crucial need to study the phenomena occurring during the operation, such as physico-chemical and biological ones. The disparities between RE values may also be due to the accuracy of the RE determination itself, which is based on measurements carried out in the gaseous phase. It should be noted that severe conditions exist in these apparatus due to the presence of dust and moisture, which increases the aggressive nature of ammonia. As a result, a more robust technique is needed to determine the real performance of biotrickling filters in operation. In summary, understanding why the monitored removal efficiencies do not meet expectations could explain the differences between calculated predictions and actual performance in operation, assisting manufacturers to propose apparatus improvements.

The objective of this work is to develop a new, simple way of determining the amount of nitrogen transferred between gas and liquid and accumulated in the washing water of biotrickling filters. The new method proposed in this paper is based on the relationship which exists between the ionic nitrogen concentration in water (i.e., sum of ammonium $\mathrm{NH}_{4}{ }^{+}$, nitrite $\mathrm{NO}_{2}{ }^{-}$and nitrate $\mathrm{NO}_{3}{ }^{-}$) and the electrical conductivity (EC) of the scrubbing liquid. By measuring the accumulated nitrogen in water (in $\mathrm{g}_{\mathrm{N}}$ day $^{-1}$ or its equivalent $\mathrm{mS} \mathrm{cm}^{-1}$ day $^{-1}$ ), the real performance of any biotrickling filter can be characterized and analyzed. The method was tested to characterize a pilot-scale biotrickling filter treating ammonia emissions generated by 60 fattening pigs.

\section{Amount of Nitrogen Accumulated in Water}

To establish the nitrogen mass balance in the biotrickling filter, the considered system involved the whole biotrickling filter (dashed rectangle in Figure 1). The mass balance can be expressed as: Nitrogen entering the system $=$ Nitrogen leaving the system + Nitrogen transferred from the gas phase and accumulated into the liquid phase + Nitrogen assimilated by the biomass.

Considering that the ammonia in the biotrickling filter is biologically converted, ammonia $\left(\mathrm{NH}_{3}\right)$ and nitrous oxide $\left(\mathrm{N}_{2} \mathrm{O}\right)$ must be taken into account in the gas phase, whereas free ammonia $\left(\mathrm{NH}_{3, \mathrm{~L}}\right)$, ammonium $\left(\mathrm{NH}_{4}{ }^{+}\right)$, hydroxylamine $\left(\mathrm{NH}_{2} \mathrm{OH}\right)$, nitrite $\left(\mathrm{NO}_{2}{ }^{-}\right)$and nitrate $\left(\mathrm{NO}_{3}{ }^{-}\right)$must be taken into account in the liquid phase in aerobic conditions (Figure 2). During nitrification, $\mathrm{N}_{2} \mathrm{O}$ generation may occur due to ammonia-oxidizing bacteria (AOB) and chemical reactions involving biological intermediates $\left(\mathrm{NH}_{2} \mathrm{OH}\right)[9,10]$. The literature data reports that maximum $\mathrm{N}_{2} \mathrm{O}$ production is around $5 \%$ of the ammonia entering the system $[11,12]$. In addition, $\mathrm{N}_{2}$ and $\mathrm{NO}_{\mathrm{x}}$ may also be produced. Taking into account the Henry's law solubility constants reported in Table 1, and given that the contact time between the gas phase and the liquid phase in biotrickling filter is usually short (in the order of 1-2 s), it can be considered that the amount of $\mathrm{N}_{2}$ and $\mathrm{N}_{2} \mathrm{O}$ entering the system and absorbed in water is insignificant. In addition, substances potentially generated by the biological activity in water $\left(\mathrm{N}_{2} \mathrm{O}, \mathrm{N}_{2}\right.$ and $\left.\mathrm{NO}_{\mathrm{x}}\right)$ are inevitably stripped and reemitted into the air. As a result, the mass balance equation is,

$$
G C_{N_{3}}^{\text {in }}+G C_{N_{2} \mathrm{O}}^{\text {in }}+L C_{L}^{\text {in }}=G C_{N_{3}}^{\text {out }}+G C_{N_{2} \mathrm{O}}^{\text {out }}+G C_{\text {stripped }}^{\text {out }}+W_{\text {drop }} C_{W}+V_{W} \frac{d\left(\text { biomass }_{N}\right)}{d t}+V_{W} \frac{d C_{W}}{d t}
$$


where $\left(G \mathrm{C}_{\mathrm{NH}_{3}}^{\mathrm{in}}\right)$ and $\left(\mathrm{GC}_{\mathrm{NH}_{3}}^{\mathrm{out}}\right)$ are the gaseous ammonia mass flow rates entering, and leaving the system, respectively. While, $\left(G C_{\mathrm{N}_{2} \mathrm{O}}^{\mathrm{in}}\right)$ and $\left(G \mathrm{C}_{\mathrm{N}_{2} \mathrm{O}}^{\text {out }}\right)$ are the gaseous nitrous oxide mass flow rates entering, and leaving the system, respectively, $\left(L C_{L}^{i n}\right)$ is the amount of nitrogen contained in the fresh water (make-up water) entering the system to replace the amount of evaporated water, $\left(G C_{\text {stripped }}^{\text {out }}\right)$ is the mass flow rate of other nitrogenous substances potentially generated by the biological activity in the scrubbing liquid, except $\mathrm{N}_{2} \mathrm{O}$ (i.e., $\left.\mathrm{N}_{2}, \mathrm{NO}_{\mathrm{x}}\right),\left(W_{\text {drop }} C_{W}\right)$ is the mass flow rate of nitrogen substances potentially leaving the system by droplet entrainment, $\left(V_{W} \frac{d\left(\text { biomass }_{N}\right)}{d t}\right)$ is the consumption rate of nitrogen used for growth of microorganisms, and $\left(V_{W} \frac{d C_{W}}{d t}\right)$ is the nitrogen mass accumulated in water in the forms ammonium, nitrite and nitrate ions (called $\varphi$ ). Assuming that the presence of an efficient demister prevents droplet entrainment, Equation (1) can be rewritten as:

$$
\varphi=V_{W} \frac{d C_{W}}{d t}=G\left(C_{N_{3}}^{\text {in }}-C_{N H_{3}}^{\text {out }}\right)+L C_{L}^{\text {in }}+G\left(C_{N_{2} \mathrm{O}}^{\text {in }}-C_{N_{2} \mathrm{O}}^{\text {out }}\right)-G C_{\text {stripped }}^{\text {out }}-V_{W} \frac{d\left(\text { biomass }_{N}\right)}{d t} .
$$

The nitrogen accumulation in water $\varphi$ can be compared to the maximum amount of ammonia entering the system, i.e., $\varphi_{\max }=\left(G C_{N_{3}}^{i n}\right)$. Thus:

$$
\begin{gathered}
\frac{\varphi}{\varphi_{\max }}=\frac{\left(C_{N H_{3}}^{\text {in }}-C_{N H_{3}}^{\text {out }}\right)}{C_{N H_{3}}^{i n}}+\frac{L C_{L}^{i n}}{G C_{N H_{3}}^{\text {in }}}+\frac{\left(C_{N_{2} \mathrm{O}}^{\text {in }}-C_{N_{2} \mathrm{O}}^{\text {out }}\right)}{C_{N H_{3}}^{\text {in }}}-\frac{C_{\text {stripped }}^{\text {out }}}{C_{N H_{3}}^{\text {in }}}-\frac{V_{W}}{G C_{N H_{3}}^{\text {in }}} \frac{d\left(\text { biomass }_{N}\right)}{d t} \\
\frac{\varphi}{\varphi_{\max }}=R E+\frac{L C_{L}^{i n}}{G C_{N H_{3}}^{\text {in }}}+\frac{\left(C_{N_{2} \mathrm{O}}^{\text {in }}-C_{N_{2} \mathrm{O}}^{\text {out }}\right)}{C_{N H_{3}}^{\text {in }}}-\frac{C_{\text {stripped }}^{\text {out }}}{C_{N H_{3}}^{\text {in }}}-\frac{V_{W}}{G C_{N H_{3}}^{\text {in }}} \frac{d\left(\text { biomass }_{N}\right)}{d t}
\end{gathered}
$$

In a first approach, it can be assumed that (i) the nitrogen concentration in the fresh water is low and consequently the term $L C_{L}^{i n}$ is insignificant with regard to the amount of gaseous nitrogen entering the system $\mathrm{GC}_{\mathrm{NH}_{3}}^{\text {, }}$ (ii) the amount of nitrogen assimilated by the biomass is also low with regard to the amount of nitrogen entering the system [13], and as a result the term $d\left(\right.$ biomass $\left._{N}\right) /\left(G C_{N H_{3}}^{i n} d t\right)$ can reasonably be ignored. Equation (4) can therefore be simplified as:

$$
\frac{\varphi}{\varphi_{\max }}=R E+\frac{\left(C_{N_{2} \mathrm{O}}^{\text {in }}-C_{N_{2} \mathrm{O}}^{\text {out }}\right)}{C_{N H_{3}}^{\text {in }}}-\frac{C_{\text {stripped }}^{\text {out }}}{C_{N H_{3}}^{\text {in }}}
$$

In Equation (5), RE is the ammonia removal efficiency determined by direct measurement of the ammonia concentrations at the inlet and the outlet of the biotrickling filter, respectively. Since $\mathrm{N}_{2} \mathrm{O}$ is produced in the apparatus, the term $\left(C_{\mathrm{N}_{2} \mathrm{O}}^{\mathrm{in}}-C_{\mathrm{N}_{2} \mathrm{O}}^{\mathrm{O}}\right)$ is $<0$ and consequently the ratio $\varphi / \varphi_{\max }$ is lower than RE. In other words, compared to the removal efficiency deduced from gaseous measurement, the ratio $\varphi / \varphi_{\max }$ has the advantage of taking into account the amount of nitrogen transferred to the water in the form of 'ammonia' and reemitted into the atmosphere in the forms $\mathrm{N}_{2} \mathrm{O}, \mathrm{N}_{2}$ and $\mathrm{NO}_{\mathrm{x}}$.

The nitrogen accumulation rate in the water $\varphi=V_{W} \frac{d C_{W}}{d t}$ is easily deduced from the relationship between the electrical conductivity of the water and the total concentration of nitrogen elements dissolved in it, as established in Part A:

$$
C_{W}=\Sigma\left(\left[\mathrm{NH}_{4}^{+}\right]+\left[\mathrm{NO}_{2}^{-}\right]+\left[\mathrm{NO}_{3}^{-}\right]\right)_{\mathrm{gN} / \mathrm{L}}=0.22 \mathrm{EC}_{\mathrm{mS} / \mathrm{cm} .}
$$

Consequently, continuous measurement of the electrical conductivity at regular intervals (hourly or daily) should allow monitoring of the amount of nitrogen accumulation rate in the water:

$$
\varphi=0.22 V_{w} \frac{E C_{(t 2)}-E C_{(t 1)}}{t 2-t 1}
$$




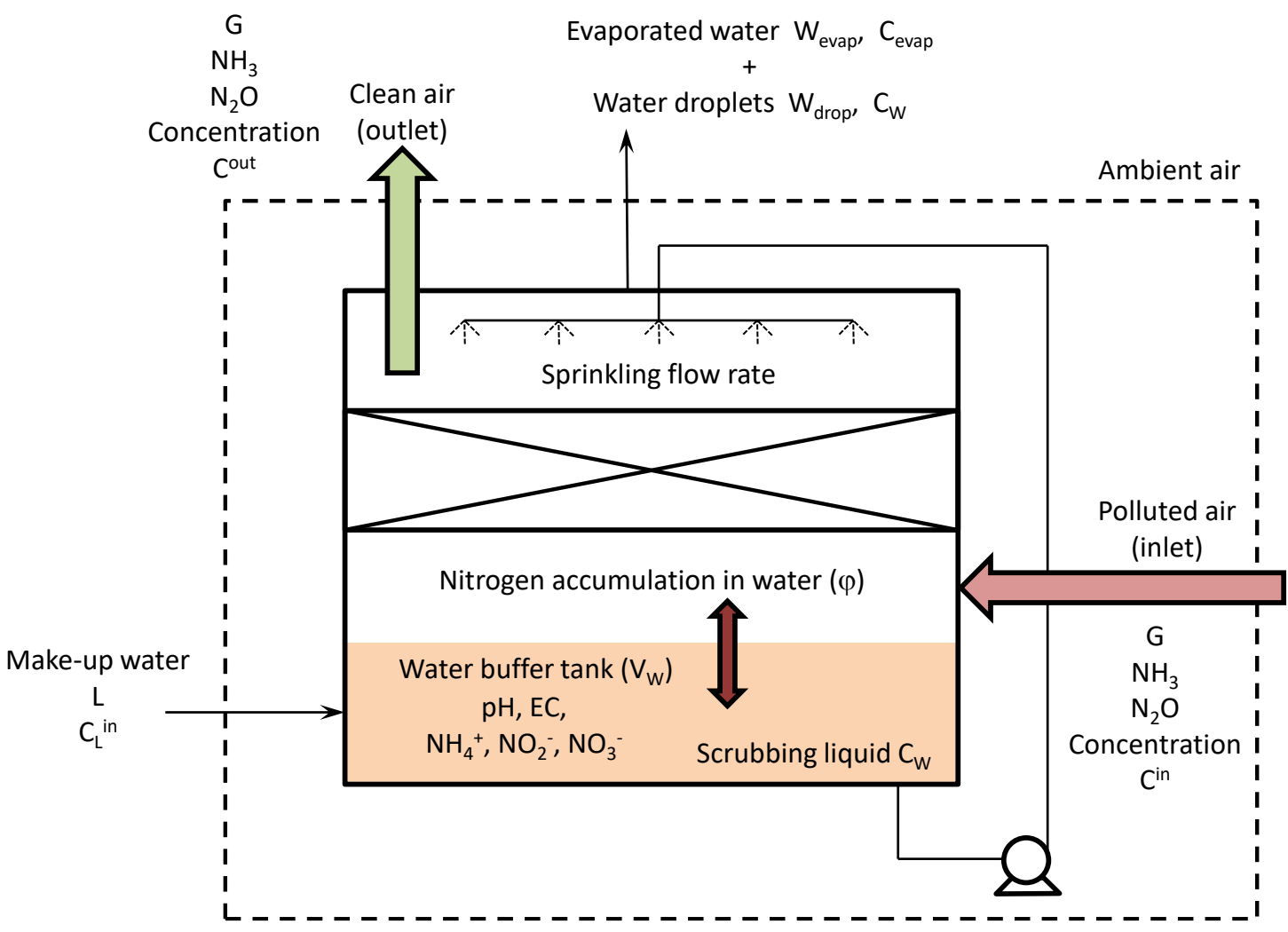

Figure 1. Schematic representation of the biotrickling filter ( $G$ : gas flow rate, $\mathrm{m}^{3} \mathrm{~h}^{-1}$; L: fresh liquid flow rate (make-up water), $\mathrm{m}^{3} \mathrm{~h}^{-1} ; W_{\text {evap }}$ : evaporated water flow rate, $\mathrm{m}^{3} \mathrm{~h}^{-1} ; W_{\text {drop }}$ : droplet entrainment flow rate, $\mathrm{m}^{3} \mathrm{~h}^{-1} ; C_{\text {evap }}$ : nitrogen concentration in evaporated water $\left(=0 \mathrm{gN} \mathrm{L}^{-1}\right) ; \mathrm{C}_{\mathrm{W}}$ : nitrogen concentration in water, $\mathrm{gN} \mathrm{L}^{-1} ; V_{W}$ : water volume in the tank, $\mathrm{m}^{3}$ ).

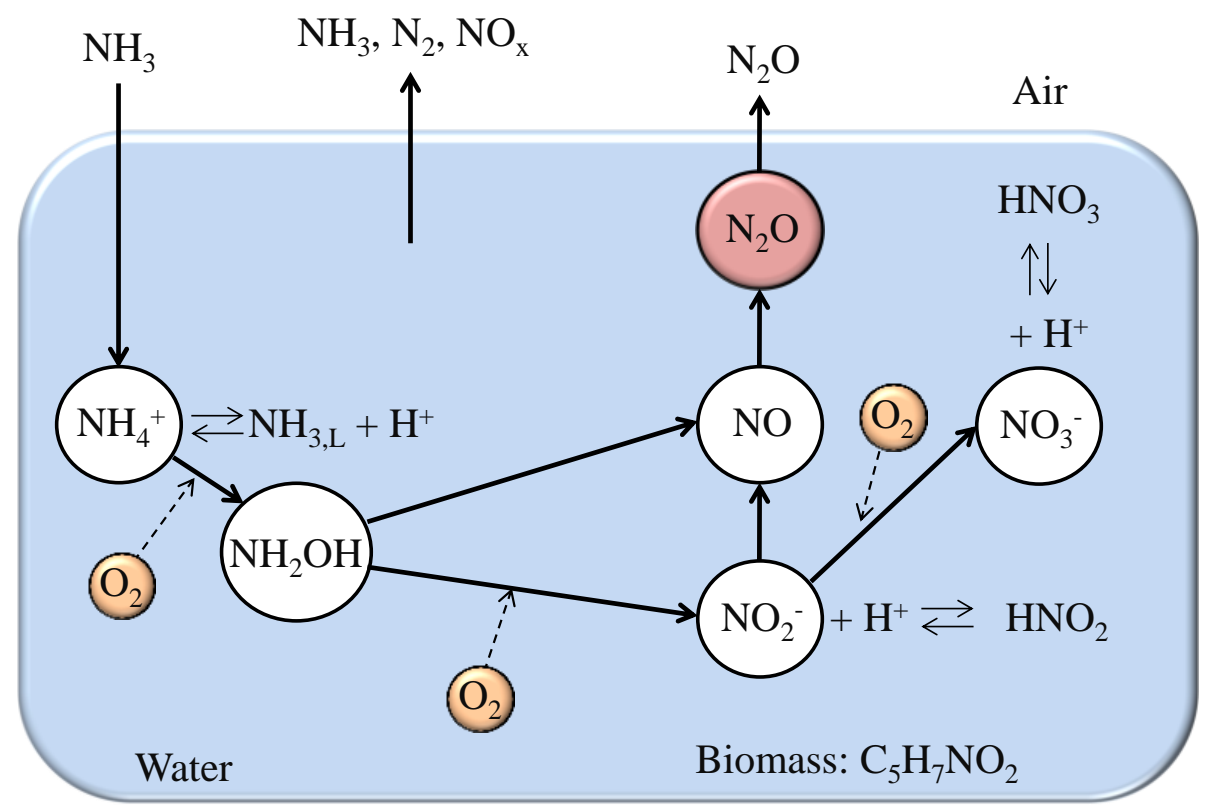

Figure 2. Nitrogen species in water. 
Table 1. Henry's law solubility constants at $298.15 \mathrm{~K}$ [14].

\begin{tabular}{cc}
\hline Substance & $\mathbf{H}=C_{\text {Gas }} / C_{\text {Liquid }}$ (Dimensionless) \\
\hline Ammonia $\left(\mathrm{NH}_{3}\right)$ & $6.84 \times 10^{-4}$ \\
Nitrogen $\left(\mathrm{N}_{2}\right)$ & 63.1 \\
Nitrous oxide $\left(\mathrm{N}_{2} \mathrm{O}\right)$ & 1.68 \\
Nitric oxide $(\mathrm{NO})$ & 21.2 \\
Nitrogen dioxide $\left(\mathrm{NO}_{2}\right)$ & 2.88 \\
Nitrogen trioxide $\left(\mathrm{NO}_{3}\right)$ & 1.06 \\
Nitrous acid $\left(\mathrm{HNO}_{2}\right)$ & $8.41 \times 10^{-4}$ \\
Nitric acid $\left(\mathrm{HNO}_{3}\right)$ & $1.92 \times 10^{-7}$ \\
\hline
\end{tabular}

\section{Description of Biotrickling Filter}

The method was applied to a pilot-scale biotrickling filter treating ammonia pollution generated by 60 fattening pigs. Measurements were carried out in 2 campaigns of 3 months (from 16 February 2018 to 18 May 2018 and from 20 November 2018 to 25 February 2019, respectively) at the IFIP experimental pig farm located in Romillé (France). The biotrickling filter was filled with a structured plastic packing: WAT NET 150 NC 20/48 $\left(V_{\text {packing material }}=0.365 \mathrm{~m}^{3}\right.$; specific surface area $\left.125 \mathrm{~m}^{2} \mathrm{~m}^{-3}\right)$ purchased from WaluTech Company (Germany). The airflow rate $(G)$ was $1350 \mathrm{~m}^{3} \mathrm{~h}^{-1}$, corresponding to an Empty Bed Residence Time (EBRT) of $1 \mathrm{~s}$. The water volume $\left(V_{W}\right)$ in the buffer tank was $548 \mathrm{~L}$. For measurement campaign \#1, the packing material was clean and no activated sludge was added to the water tank for inoculation. For measurement campaign \#2, the packing material was not clean (the fixed biomass was retained) and salty water was replaced by fresh water at $t=0$. Parameters (EC, $\mathrm{pH}$ and temperature for the liquid phase; gas flow rate and ammonia concentrations for the gas phase) were measured daily. Electrical measurement was carried out using an EC meter (WTW Cond 340i, Weilheim, Germany) with temperature correction. The $\mathrm{pH}$ was measured using a multi-channel analyzer consort $\mathrm{C} 834$ (Consort bvba, Turnhout, Belgium) with temperature correction. The gas flow rate was determined by continuous measurement of the air velocity. The extractor fan for the upper part of the room was equipped with a full-size free-running impeller unit connected to a central datalogger to record the rotation speed every $15 \mathrm{~min}$ (FANCOM system; Panningen, Netherlands). The flow rate was therefore calculated according to the section of the fan. Concentrations of ammonia $\left(\mathrm{NH}_{3}\right)$ and nitrous oxide $\left(\mathrm{N}_{2} \mathrm{O}\right)$ were measured using an InfraRed-photoacoustic system (1412 Photoacoustic Field Gas Monitor, Innova LumaSense Technologies) with compensated interferences between gases. The ammonia removal efficiency $(R E)$ was calculated using the inlet and outlet $\mathrm{NH}_{3}$ gas concentrations respectively $\left(\mathrm{RE}=100\left(\mathrm{C}_{\mathrm{NH}_{3}}^{\mathrm{in}}-\mathrm{C}_{\mathrm{NH}_{3}}^{\text {out }}\right) / \mathrm{C}_{\mathrm{NH}_{3}}^{\mathrm{in}} ; \%\right)$.

\section{Results}

\subsection{Experiment Results}

The results obtained for the two measurement campaigns are shown in Figure 3. Ammonia concentrations in the air at the biotrickling filter inlet ranged from 10 to $25 \mathrm{mg} \mathrm{m}^{-3}$ for campaign $\# 1$ (which corresponds to values reported in the literature $[8,15]$ ) and usually close to $25 \mathrm{mg} \mathrm{m}^{-3}$ in campaign \#2. As a result, the ammonia load to be treated was more regular for campaign \#2 (around 30-36 $\mathrm{g}_{\mathrm{N}} \mathrm{h}^{-1}$ i.e., 82-99 $\mathrm{g}_{\mathrm{N}} \mathrm{h}^{-1} \mathrm{~m}^{-3}$ packing material; Figure 3A) than for campaign \#1 (from 13 to $39 \mathrm{~g}_{\mathrm{N}} \mathrm{h}^{-1}$ corresponding to $34-107 \mathrm{~g}_{\mathrm{N}} \mathrm{h}^{-1} \mathrm{~m}^{-3}$ packing material). As observed in Figure $3 \mathrm{~B}$, monitoring the electrical conductivity of the scrubbing liquid allowed characterization of the nitrogen accumulation in the water of the biotrickling filter and consequently confirmation whether the apparatus was functioning properly. Three distinct phases can therefore be distinguished for each campaign (the main results are reported in Table 2). 
Campaign \#1

(A)

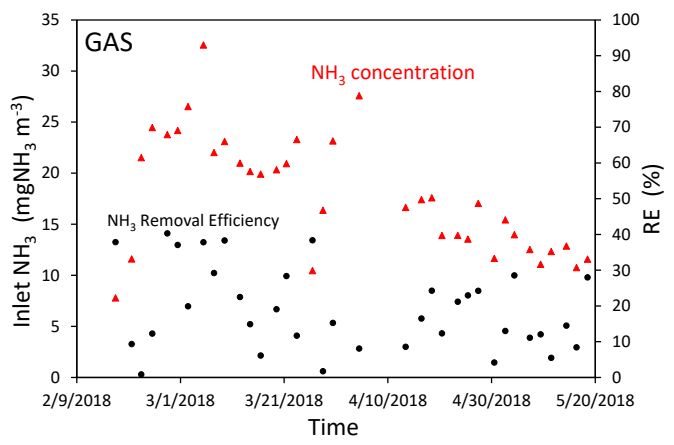

(B)

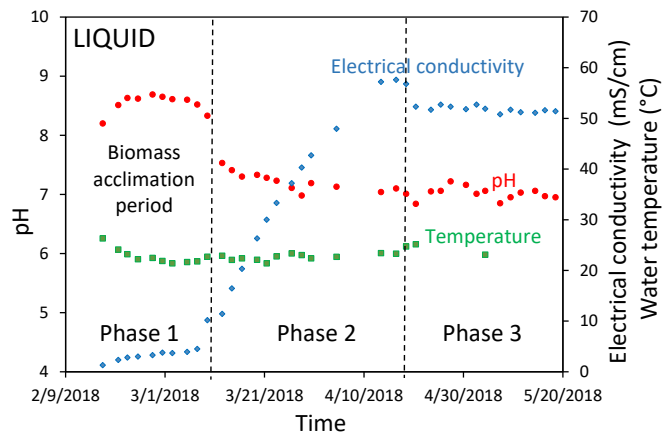

(C)

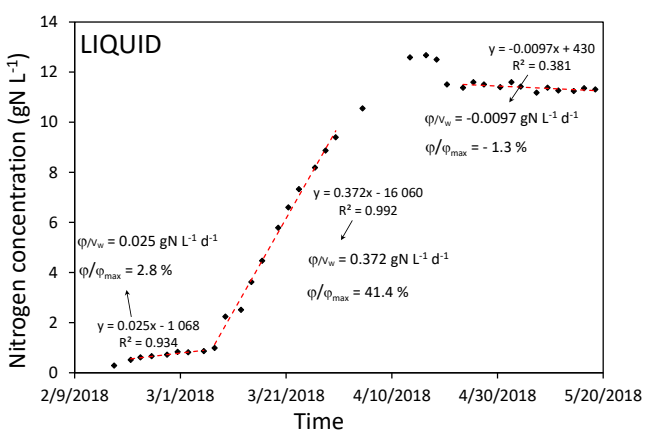

Campaign \#2
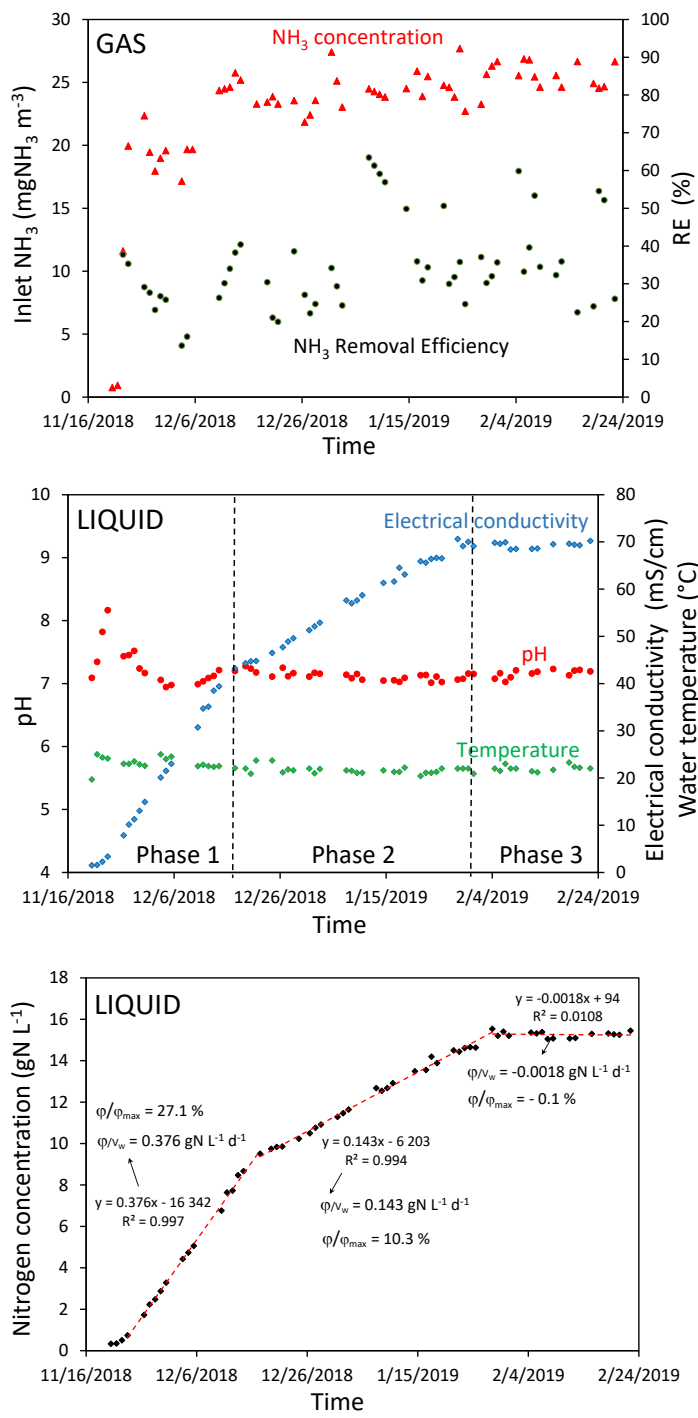

Figure 3. Experiment results recorded for campaigns \#1 and \#2. (A) Ammonia concentration in the air entering the biotrickling filter and ammonia removal efficiency determined from measurement in the gas phase; (B) Parameters measured for the scrubbing liquid in the buffer tank (temperature, $\mathrm{pH}$ and electrical conductivity); (C) Total nitrogen concentration in the scrubbing liquid deduced from the electrical conductivity measurement (Equation (6)).

(i) For campaign \#1 (i.e., clean packing material and fresh water without biomass inoculation), phase 1 corresponds to the acclimation period of the biomass, characterized by a slow increase in EC and consequently a slow increase in the amount of nitrogen accumulated in water $\varphi$ calculated from Equation (7) (13.6 $\mathrm{g}_{\mathrm{N}} \mathrm{d}^{-1}$ i.e., $0.025 \mathrm{~g}_{\mathrm{N}} \mathrm{L}^{-1} \mathrm{~d}^{-1}$ for the first 3 weeks of the experiment; Figure 3C). The acclimation period of the biomass was confirmed by monitoring the $\mathrm{pH}$ (Figure $3 \mathrm{~B}$ ). At the beginning of the experiment, the $\mathrm{pH}$ of the water initially increased (up to 8.5) in relation to the absorption of ammonia and its conversion into ammonium ions $\left(\mathrm{NH}_{3}+\mathrm{H}_{2} \mathrm{O} \rightarrow \mathrm{NH}_{4}{ }^{+}+\mathrm{OH}^{-}\right)$. A significant drop in the $\mathrm{pH}$, characterizing the end of the acclimation period, was then observed indicating that $\mathrm{OH}^{-}$ions were progressively neutralized during the nitrification process of ammonium ions into nitrite ions $\left(\mathrm{NH}_{4}{ }^{+}+3 / 2 \mathrm{O}_{2} \rightarrow \mathrm{NO}_{2}{ }^{-}+2 \mathrm{H}^{+}+\mathrm{H}_{2} \mathrm{O}\right)$. Consequently, the nitrifying bacteria involved at the nitrification stage allowed the $\mathrm{pH}$ to stabilize at around 7.0. During the acclimation period (and the whole experiment in general), the ammonia removal efficiency determined from 
gaseous measurements fluctuated from 0 to $+40 \%$, which does not lead to any clear conclusion (Figure $3 \mathrm{~A})$. Conversely, determination of the amount of nitrogen accumulated in water $\varphi\left(13.6 \mathrm{~g}_{\mathrm{N}} \mathrm{d}^{-1}\right)$ as well as the ratio $\varphi / \varphi_{\max }(2.8 \%)$ demonstrate that only a small amount of the nitrogen entering the biotrickling filter was actually absorbed and retained in the water (Figure 3C), which confirms the utility of monitoring the EC.

Table 2. Main results calculated for campaigns \#1 and \#2.

\begin{tabular}{|c|c|c|c|}
\hline & & Campaign \#1 & Campaign \#2 \\
\hline \multirow{5}{*}{ Phase 1} & $\varphi / V_{W}\left(\mathrm{gN} \mathrm{L}^{-1} \mathrm{~d}^{-1}\right)$ & 0.0248 & 0.376 \\
\hline & $\varphi /\left(0.22 V_{W}\right)\left(\mathrm{mS} \mathrm{cm}^{-1} \mathrm{~d}^{-1}\right)$ & 0.113 & 1.71 \\
\hline & $\varphi\left(\mathrm{gN} \mathrm{d}^{-1}\right)$ & 13.6 & 206.2 \\
\hline & $\varphi / \varphi_{\max }(\%)$ & 2.8 & 27.1 \\
\hline & Nitrogen accumulated in water $\left(\mathrm{gN} \mathrm{h}^{-1} \mathrm{~m}^{-3}\right.$ packing material $)$ & 1.6 & 23.6 \\
\hline \multirow{5}{*}{ Phase 2} & $\varphi / V_{W}\left(\mathrm{gN} \mathrm{L}^{-1} \mathrm{~d}^{-1}\right)$ & 0.372 & 0.143 \\
\hline & $\varphi /\left(0.22 V_{W}\right)\left(\mathrm{mS} \mathrm{cm}^{-1} \mathrm{~d}^{-1}\right)$ & 1.69 & 0.65 \\
\hline & $\varphi\left(\mathrm{gN} \mathrm{d}^{-1}\right)$ & 203.9 & 78.4 \\
\hline & $\varphi / \varphi_{\max }(\%)$ & 41.4 & 10.3 \\
\hline & Nitrogen accumulated in water $\left(\mathrm{gN} \mathrm{h}^{-1} \mathrm{~m}^{-3}\right.$ packing material $)$ & 23.3 & 9.0 \\
\hline \multirow{5}{*}{ Phase 3} & $\varphi / V_{W}\left(\mathrm{gN} \mathrm{L}^{-1} \mathrm{~d}^{-1}\right)$ & -0.0097 & -0.0018 \\
\hline & $\varphi /\left(0.22 V_{W}\right)\left(\mathrm{mS} \mathrm{cm}^{-1} \mathrm{~d}^{-1}\right)$ & -0.044 & -0.0069 \\
\hline & $\varphi\left(\mathrm{gN} \mathrm{d}^{-1}\right)$ & -5.3 & -0.8 \\
\hline & $\varphi / \varphi_{\max }(\%)$ & -1.3 & -0.1 \\
\hline & Nitrogen accumulated in water $\left(\mathrm{gN} \mathrm{h}^{-1} \mathrm{~m}^{-3}\right.$ packing material $)$ & -0.6 & -0.1 \\
\hline
\end{tabular}

Phase 2 of campaign \#1 was characterized by a significant increase in the electrical conductivity of the water, indicating that nitrogen mass transfer occurred between phases in the biotrickling filter. The nitrogen accumulation was therefore constant during this phase ( $\varphi$ around $203.9 \mathrm{~g}_{\mathrm{N}} \mathrm{d}^{-1}$ ) although a slight decrease at the end of the phase 2 was observed (Figure 3C). Once EC reached a value of around $50-60 \mathrm{mS} \mathrm{cm}^{-1}$, no further increase was observed. Phase 3 of campaign \#1 can therefore be interpreted as a balance between the amount of nitrogen absorbed in the water in the form of $\mathrm{NH}_{3}$ and the amount of nitrogen stripped from water in the form of $\mathrm{NH}_{3}, \mathrm{~N}_{2} \mathrm{O}, \mathrm{N}_{2}$ and $\mathrm{NO}_{\mathrm{x}}$.

(ii) For campaign \#2 (i.e., packing material not cleaned and addition of fresh water at $t=0$ ), the monitoring of the water's electrical conductivity indicated that the presence of an acclimated biomass attached to the packing material allowed rapid restoration of the biotrickling filter's capacity to transfer ammonia between the gas and liquid phases, and promotion of the nitrification process. This finding was confirmed by a rapid change in the $\mathrm{pH}$ at the beginning of the experiment (Figure 3B). Phase 1 of this campaign is therefore characterized by a nitrogen accumulation in water $\varphi$ of around $206.2 \mathrm{~g}_{\mathrm{N}} \mathrm{d}^{-1}$; i.e., similar to the value determined in phase 2 of campaign \#1. Incidentally, it is interesting to superimpose the results of the two campaigns with a correct time offset (Figure 4). As observed, a shift of 16 days is required to match the curves accurately, which allows the influence of the acclimated biomass to be quantified. It also appears that changes of between 5 and $40 \mathrm{mS} \mathrm{cm}^{-1}$ in the electrical conductivity of the water were identical for both campaigns, whereas the ammonia inlet load to be treated was greater for campaign \#2 than for campaign \#1 (implying that ratios $\varphi / \varphi_{\max }$ were different for each experiment: $41 \%$ and $27 \%$ for campaign $\# 1$, and \#2, respectively; Figure 3C). For the applied operating conditions $(E B R T=1 \mathrm{~s})$, the maximum nitrogen accumulation in the water of the biotrickling filter was around $24 \mathrm{gN} \mathrm{h}^{-1} \mathrm{~m}^{-3}$ packing material. This value is in the same order of magnitude as the removal capacity $\left(R C=G\left(\mathrm{C}_{\mathrm{NH}_{3}}^{\mathrm{in}}-\mathrm{C}_{\mathrm{NH}_{3}}^{\text {out }}\right) / V_{\text {packing material }}\right)$ reported in the literature for the removal of ammonia by a full scale biotrickling filter operating under the same conditions [11]. For comparison, higher removal capacities can be found in the literature [16], but these results are usually obtained for laboratory-scale biotrickling filters operating at significant higher EBRT. 


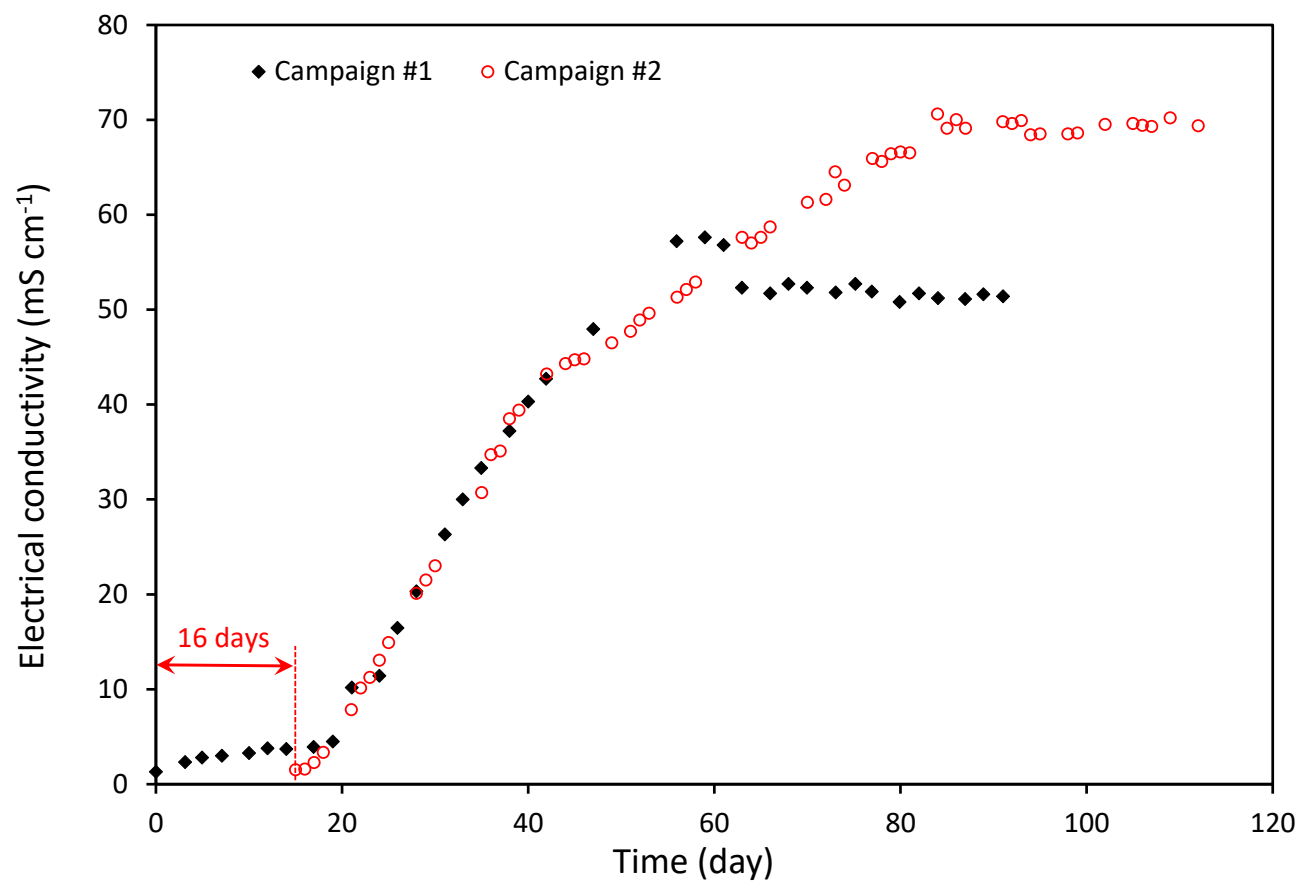

Figure 4. Comparison between EC changes recorded for campaigns \#1 and \#2. A shift of 16 days was applied to the results for campaign \#2 to match the two curves accurately and to take the biomass acclimation period recorded in campaign \#1 into account.

Phase 2 of campaign \#2 was characterized by a decrease in the change in the electrical conductivity of the water, indicating a reduction in ammonia mass transfer. Nonetheless, the nitrogen accumulation in the water was regular ( $\varphi$ around $78.4 \mathrm{~g}_{\mathrm{N}} \mathrm{d}^{-1}$ ) for the EC ranging between 40 and $70 \mathrm{mS} \mathrm{cm}^{-1}$ (Figure 3B). Once an EC value of around $70 \mathrm{mS} \mathrm{cm}^{-1}$ was achieved, the EC stopped increasing and remained roughly constant (phase 3). As in phase 3 of campaign \#1, a balance was obtained between the amount of nitrogen absorbed in the scrubbing liquid in the form of $\mathrm{NH}_{3}$ and the amount of nitrogen stripped in the form of $\mathrm{NH}_{3}, \mathrm{~N}_{2} \mathrm{O}, \mathrm{N}_{2}$ and $\mathrm{NO}_{\mathrm{x}}\left(\varphi=-0.8 \mathrm{~g}_{\mathrm{N}} \mathrm{d}^{-1}\right)$.

\subsection{Influence of EC Value}

From the results recorded in each campaign, two significant similarities are to be highlighted (Figure 4). The first is that the nitrogen accumulated in the scrubbing liquid $\varphi$ was roughly constant for an EC ranging between 5 and $40 \mathrm{mS} \mathrm{cm}^{-1}$ (around $205 \mathrm{~g}_{\mathrm{N}} \mathrm{d}^{-1}$ ). The second is that for higher EC values, the nitrogen accumulation slowed down and stopped for ECs of around $50-60 \mathrm{mS} \mathrm{cm}^{-1}$ (campaign \#1) and $70 \mathrm{mS} \mathrm{cm}{ }^{-1}$ (campaign \#2). Consequently, it can be argued that the biotrickling filter's ability to remove ammonia is partially controlled by the EC value and more precisely by the amount of nitrogen present in the scrubbing liquid (i.e., $C_{W}=\Sigma\left(\left[\mathrm{NH}_{4}{ }^{+}\right]+\left[\mathrm{NO}_{2}{ }^{-}\right]+\left[\mathrm{NO}_{3}{ }^{-}\right]\right.$; it was verified that the correlation established in Part A could be applied to $E C$ values up to $70 \mathrm{mS} \mathrm{cm}^{-1}$; not shown). Basically, the control can be due to either mass transfer limitation or inhibition of the nitrifying bacteria. These phenomena can also occur concomitantly. Assuming in a first approach that the nitrification process is not inhibited where there is a high nitrogen concentration in the liquid phase (this item is discussed later), the suspension of the nitrogen accumulation would necessarily be due to the fact that the driving force represented by the difference in ammonia concentration between the air and the scrubbing liquid $\left(\mathrm{C}_{\mathrm{NH}_{3}}^{\mathrm{in}} / \mathrm{H}-\mathrm{C}_{\mathrm{NH}_{3}, \mathrm{~L}}\right)$ is nil in the following equation,

$$
\varphi=\mathrm{K}_{\mathrm{L}} \mathrm{a}\left(\frac{\mathrm{C}_{\mathrm{NH}}^{\mathrm{in}}}{\mathrm{H}}-\mathrm{C}_{\mathrm{NH}_{3}, L}\right) V_{W}
$$


where $\mathrm{C}_{\mathrm{NH}_{3}}^{i n}$ is the ammonia concentration of the air entering the biotrickling filter $\left(\mathrm{kg}_{\mathrm{NH}_{3}} \mathrm{~m}^{-3}\right)$, $\mathrm{H}$ is the dimensionless Henry coefficient (Table 1), $\mathrm{C}_{\mathrm{NH}_{3}, \mathrm{~L}}$ is the free ammonia concentration in the scrubbing liquid $\left(\mathrm{kg}_{\mathrm{NH}_{3}} \mathrm{~m}^{-3}\right)$ and $K_{\mathrm{L}} a$ is the overall mass transfer coefficient dependent mainly on the hydrodynamics of the biotrickling filter $\left(\mathrm{s}^{-1}\right)$. In the scrubbing liquid (volume $V_{W}$ ), a chemical equilibrium exists between the ammonium and the free ammonia concentrations, which depends on both the $\mathrm{pH}$ and the acid dissociation constant $\left(\mathrm{pK}_{\mathrm{a}}=-\log _{10}\left(1.163910^{-10} \exp (0.0463 \mathrm{~T})\right) ; T\left({ }^{\circ} \mathrm{C}\right)[17]\right)$ :

$$
\mathrm{C}_{\mathrm{NH}_{3}, \mathrm{~L}}=\left[\mathrm{NH}_{4}{ }^{+}\right] 10^{(-\mathrm{pKa}+\mathrm{pH})} \text {. }
$$

Given that the ammonium concentration in the scrubbing liquid can be related to the electrical conductivity of the water $\left(\mathrm{NH}_{4}{ }^{+}{ }_{\mathrm{gN} / \mathrm{L}}=0.11 \mathrm{EC}_{\mathrm{mS} / \mathrm{cm}}\right.$; see Part A), Equation (9) can be written:

$$
\mathrm{C}_{\mathrm{NH}_{3}, \mathrm{~L}}=0.11 \mathrm{EC} 10^{(-\mathrm{pKa}+\mathrm{pH})} \text {. }
$$

And consequently, for an ammonia concentration of the air entering the biotrickling filter expressed in $\mathrm{mg}_{\mathrm{NH}_{3}} \mathrm{~m}^{-3}$, the driving force would be nil if:

$$
E C=\frac{14}{17 \times 10^{6}} \frac{C_{N H_{3}}^{i n}}{0.11 H 10^{(-p K a+p H)}} .
$$

Therefore, the value that the EC must reach, in order to cause suspension of the nitrogen accumulation depends on the following parameters: (i) The ammonia concentration to be treated; (ii) the $\mathrm{pH}$ of the scrubbing liquid; (iii) the $\mathrm{pKa}$ value and (iv) the Henry coefficient. The pKa value and the Henry coefficient, which depends on the temperature of the physicochemical properties of the scrubbing liquid, can be determined from the literature data. Although, the accuracy of these parameters must be taken into account, it appears that suspension of the nitrogen accumulation is mainly influenced by $\mathrm{pH}$ and ammonia concentration (Figure 5). As observed in this figure, the EC values calculated using Equation (11) for the experimental conditions recorded in phase 3 of each campaign (i.e., $\mathrm{pH}$ around 7.0 and $\mathrm{C}_{\mathrm{NH}_{3}}^{\text {in }}$ between 10 and $17 \mathrm{mg}_{\mathrm{NH}_{3}} \mathrm{~m}^{-3}$ for campaign \#1 and $\mathrm{pH}$ around 7.2 and $C_{\mathrm{NH}_{3}}^{\mathrm{in}}$ between 24 and $27 \mathrm{mg}_{\mathrm{NH}_{3}} \mathrm{~m}^{-3}$ for campaign \#2; Figure 3A) are in agreement with the experiment plateau values of $50-60 \mathrm{mS} \mathrm{cm}^{-1}$ and $70 \mathrm{mS} \mathrm{cm}^{-1}$ recorded in campaigns \#1 and \#2, respectively. Consequently, it can be argued that the nitrogen accumulation stopped because the driving force became nil. As a result, a purge of the scrubbing liquid must be achieved, in order to restore the ability of the apparatus to remove ammonia.

In addition to mass transfer limitation, the suspension of the nitrogen accumulation may be due to inhibition of the nitrifying bacteria. The literature reports that free $\mathrm{NH}_{3}$ and free $\mathrm{HNO}_{2}$ in water may act as inhibitory agents for ammonia oxidizing bacteria (AOB) and nitrite oxidizing bacteria (NOB), but many inhibition thresholds are given. These data are summarized and analyzed by [18] and [19]. For plateau values of $50-60 \mathrm{mS} \mathrm{cm}^{-1}$ and $70 \mathrm{mS} \mathrm{cm}^{-1}$ recorded for campaigns \#1 and \#2, it can be calculated from Equation (10) that free $\mathrm{NH}_{3}$ concentrations were 24 and $44 \mathrm{mg}_{\mathrm{NH}_{3}} \mathrm{~L}^{-1}$, respectively. These values are in the range of inhibition values reported by [20], i.e., $10-150 \mathrm{mg}_{\mathrm{NH}_{3}} \mathrm{~L}^{-1}$. Consequently, $\mathrm{AOB}$ inhibition is possible in the present case. Although, studies have reported that AOB are not inhibited by free $\mathrm{NH}_{3}$, even at high ammonia loading rates such as those encountered in this study [18]. Free $\mathrm{HNO}_{2}$ concentration in water $\left(\right.$ in $\mathrm{mg}_{\mathrm{NO} 2} \mathrm{~L}^{-1}$ ) can be calculated using the following equation given by [20]:

$$
\text { free }\left[\mathrm{HNO}_{2}\right]=\frac{46}{14} \frac{\left[\mathrm{NO}_{2}^{-}\right]}{\exp \left(\frac{-2300}{\mathrm{~T}}\right) 10 \mathrm{pH}}
$$




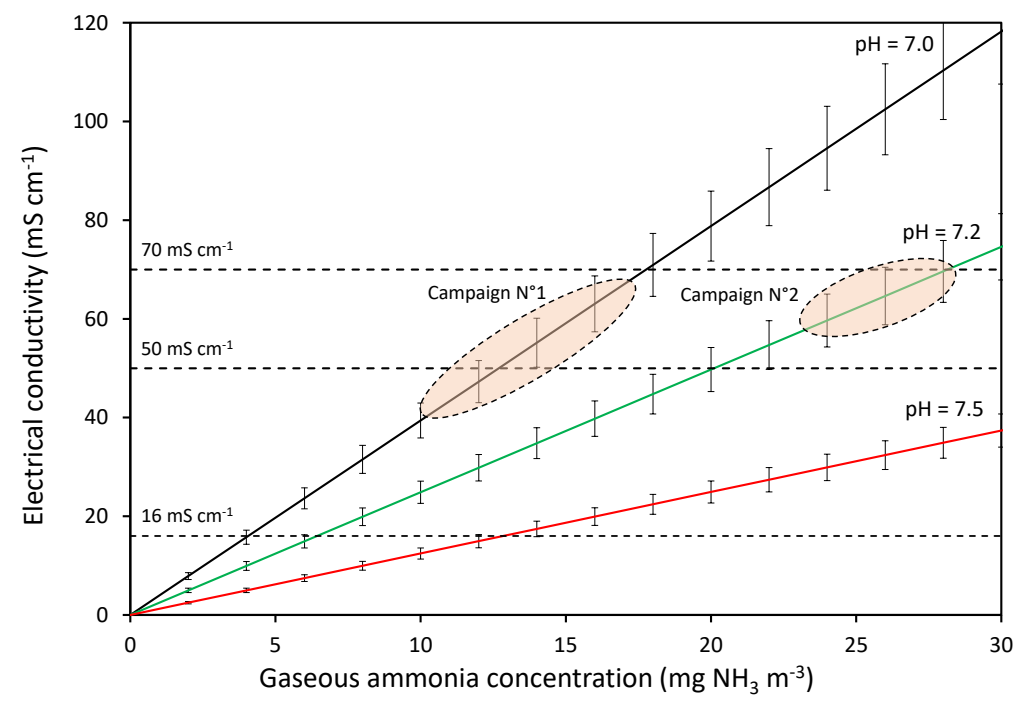

Figure 5. Lines: calculated values (Equation (11)) for the electrical conductivity of water where the ammonia driving force between phases becomes nil (i.e., equilibrium between ammonia concentration in the gas phase and free ammonia concentration in the liquid phase). pKa $=9.53$ at $22{ }^{\circ} \mathrm{C}$ [17]; Henry coefficient $H=5.8910^{-4}$ at $22{ }^{\circ} \mathrm{C}$ [21]. Error bars indicate the influence of the change in temperature of the scrubbing liquid $\left( \pm 1^{\circ} \mathrm{C}\right)$ on $\mathrm{pKa}$ and $\mathrm{H}$ calculation. Ellipses: maximum possible EC values for the experiment conditions recorded for phase 3 of campaign $\# 1$ ( $\mathrm{pH} 7.0$ and $C_{\mathrm{NH}_{3}}^{\mathrm{in}} 10-17 \mathrm{mg}_{\mathrm{NH}_{3}} \mathrm{~m}^{-3}$ ) and campaign \#2 ( $\mathrm{pH} 7.2$ and $\mathrm{C}_{\mathrm{NH}_{3}}^{\text {in }} 24-27 \mathrm{mg}_{\mathrm{NH}_{3}} \mathrm{~m}^{-3}$ ).

The minimum concentration of free $\mathrm{HNO}_{2}$ in the scrubbing liquid can be calculated by assuming an $\mathrm{NO}_{2}{ }^{-} / \mathrm{NO}_{3}{ }^{-}$ratio of 1 (i.e., $\left[\mathrm{NO}_{2}{ }^{-}\right]_{\mathrm{mgN} / \mathrm{L}}=\left[\mathrm{NH}_{4}{ }^{+}\right]_{\mathrm{mgN} / \mathrm{L}} / 2$ ) while the maximum concentration can be calculated by assuming that the amount of nitrate ions is very low with regard to the amount of nitrite ions in the water (i.e., $\left[\mathrm{NO}_{2}{ }^{-}\right]_{\mathrm{mgN} / \mathrm{L}}=\left[\mathrm{NH}_{4}{ }^{+}\right]_{\mathrm{mgN} / \mathrm{L}}$ ), which corresponds to actual cases encountered in biotrickling filters treating ammonia emissions (see Part A). For campaign \#1, free $\mathrm{HNO}_{2}$ ranged between 1.9 and $3.8 \mathrm{mg} \mathrm{L}^{-1}$, and between 1.4 and $2.8 \mathrm{mg} \mathrm{L}^{-1}$ for campaign \#2. According to [20], the inhibition of $\mathrm{NOB}$ is initiated where the free $\mathrm{HNO}_{2}$ concentration is between 0.22 and $2.8 \mathrm{mg} \mathrm{L}^{-1}$. As a result, NOB inhibition probably occurred in both campaigns. To conclude, it can be argued that the inhibition of nitrifying bacteria probably existed at these levels of EC values, which limited the nitrogen accumulation, but ultimately the suspension of the nitrogen accumulation was mainly due to the high level of ammonium ions in the scrubbing liquid, which hindered the driving force between phases.

\subsection{Advantages of EC Measurement}

Measuring the electrical conductivity of scrubbing liquid is quick and simple. In addition, industrial electrical conductivity probes are robust, reliable, accurate tools that are used in several industries under different conditions. As EC measurement is currently used to control the water quality of some industrial-scale biotrickling filters, EC values could easily be recorded (on a daily basis, for instance) to monitor changes in EC over time. A simple analysis of this change on some days, as illustrated in Figure 3B, confirms that the apparatus is functional (steady state or malfunctioning). Additionally, it appears from the relationship determined in Part A that the overall amount of nitrogen species accumulated in the scrubbing liquid of the apparatus can be evaluated. In other words, the performance of biotrickling filters used to treat gaseous emissions from pig farms (or other livestock farms, such as poultry) could be directly obtained without any sophisticated analytical apparatus, other than an electrical conductivity probe.

The simple and robust procedure applied to characterize the nitrogen accumulation from measuring the EC presents a considerable advantage of taking into account the amount of nitrogen transferred to the water in the form of $\mathrm{NH}_{3}$, and possibly reemitted into the atmosphere in the form of $\mathrm{N}_{2} \mathrm{O}$ and $\mathrm{NO}_{\mathrm{x}}$. 
As illustrated in Figure 3 (phase 3 of each campaign), EC measurement indicated an equilibrium of the nitrogen species between phases (implying ratio values $\varphi / \varphi_{\max }$ close to zero for both campaigns). Whereas, ammonia removal efficiency, deduced from gaseous measurements, fluctuated between $5 \%$ and $30 \%$ for campaign \#1 and between $20 \%$ to $60 \%$ for campaign \#2. Although, the fluctuations in RE are difficult to explain (keeping in mind that it is difficult to take measurements in the gaseous phase in biotrickling filters operating at livestock facilities, due to the presence of dust and moisture), the ratio $\varphi / \varphi \max$ has to be lower than RE (see Equation (5)), demonstrating that, at high EC levels, a significant amount of the $\mathrm{NH}_{3}$ absorbed in the scrubbing liquid could be reemitted in the form of $\mathrm{N}_{2} \mathrm{O}$ and $\mathrm{NO}_{\mathrm{x}}$.

Finally, the procedure developed in this paper is an accurate and robust tool for quantifying the nitrogen accumulation in the scrubbing liquid of a biotrickling filter. Nonetheless, the accuracy of this procedure could be improved by measuring the amount of fresh water fed into the water tank to replace the amount lost through evaporation, and by knowing the mineral composition of this fresh water. This information can then be used to check the assumption that the amount of nitrogen in the fresh water is lower than the amount of gaseous nitrogen entering the system, and consequently that the term $L C_{L}^{\text {in }}$ in Equation (4) can reasonably be ignored.

\section{Conclusions}

The nitrogen accumulation in a biotrickling filter used to treat gaseous emissions generated by pig facilities could be easily determined by measuring the electrical conductivity (EC) of the scrubbing liquid. An analysis of the EC change, over time, confirms that the apparatus is functioning (steady state or malfunctioning). Therefore, performance is hindered at high EC values due to high concentration of ammonium ions, which limit the driving force between phases. In addition, EC measurement is a reliable method of calculating the ability to treat ammonia emissions (ratio $\varphi / \varphi_{\max }$ in $\%$ and nitrogen accumulation in $\mathrm{g}_{\mathrm{N}} \mathrm{h}^{-1} \mathrm{~m}^{-3}$ packing material) without the need for sophisticated and expensive gas-phase measurements. Moreover, the ratio $\varphi / \varphi_{\max }$ provides more accurate information on the operation of the biotrickling filter than by deducing the removal efficiency from gaseous ammonia measurements, since the different nitrogen forms $\left(\mathrm{NH}_{3}\right.$ absorbed in the scrubbing liquid and nitrogen forms reemitted to the atmosphere) are taken into account.

Further investigation, on large-scale biotrickling filters, to treat ammonia emissions at livestock facilities over a long period will be carried out to study the influence that the amount of scrubbing liquid lost by evaporation and its replacement with fresh water has. These studies will reinforce the EC method for characterizing the performance of the apparatus in real time.

Author Contributions: All authors conceived and designed the experiments; S.L., N.G., A.C., L.L. and A.A. performed the experiments; S.L., N.G. and É.D. analyzed the data and results; É.D. wrote the paper; S.L., N.G., A.C., A.A. and É.D. reviewed the manuscript. All authors have read and agreed to the published version of the manuscript.

Funding: This research was funded by the French Environment and Energy Management Agency (ADEME) (project PRIMEQUAL No. 1660C0014).

Conflicts of Interest: The authors declare no conflict of interest.

\section{References}

1. REF Commission Implementing Decision (EU) 2017/302 of 15 February 2017; Establishing Best Available Techniques (BAT) Conclusions, under Directive 2010/75/EU of the European Parliament and of the Council, for the Intensive Rearing of Poultry or Pigs. 2017, Brussels, (40-42). Available online: http://eippcb.jrc.ec. europa.eu/reference/ (accessed on 9 January 2018).

2. Winkel, A.; Demeyer, P.; Feilberg, A.; Jørgensen, M.; Puterflam, J.; Engel, P. Measurement of Particulate Matter: Recommendations for the VERA Test Protocol on Air Cleaning Technologies; Wageningen UR Livestock Research: Wageningen, the Netherlands, 2014. 
3. Loyon, L.; Burton, C.H.; Misselbrook, T.; Webb, J.; Philippe, F.X.; Aguilar, M.; Doreau, M.; Hassouna, M.; Veldkamp, T.; Dourmad, J.Y.; et al. Best available technology for European livestock farms: Availability, effectiveness and uptake. J. Environ. Manag. 2016, 166, 1-11. [CrossRef] [PubMed]

4. Philippe, F.X.; Cabaraux, J.F.; Nicks, B. Ammonia emissions from pig houses: Influencing factors and mitigation techniques. Agric. Ecosyst. Environ. 2011, 141, 245-260. [CrossRef]

5. Copelli, S.; Raboni, M.; Derudi, M.; Nano, G.; Torretta, V. Comparison between absorption and biological activity on the efficiency of the biotrickling filtration of gaseous streams containing ammonia. Environ. Sci. Pollut. Res. 2017, 24, 23207-23218. [CrossRef] [PubMed]

6. Raboni, M.; Torretta, V. A modified biotrickling filter for nitrification-denitrification in the treatment of an ammonia-contaminated air stream. Environ. Sci. Pollut. Res. 2016, 23, 24256-24264. [CrossRef] [PubMed]

7. Kennes, C.; Veiga, M.C. Biotrickling Filters. In Air Pollution Prevention and Control: Bioreactors and Bioenergy, 1st ed.; John Wiley \& Sons, Ltd.: Hoboken, NJ, USA, 2013; pp. 121-138. ISBN 978-1-118-52336-0.

8. Van der Heyden, C.; Demeyer, P.; Volcke, E.I.P. Mitigating emissions from pig and poultry housing facilities through air scrubbers and biofilters: State-of-the-art and perspectives. Biosyst. Eng. 2015, 134, 74-93. [CrossRef]

9. Desloover, J.; Vlaeminck, S.E.; Clauwaert, P.; Verstraete, W.; Boon, N. Strategies to mitigate $\mathrm{N}_{2} \mathrm{O}$ emissions from biological nitrogen removal systems. Curr. Opin. Biotechnol. 2012, 23, 474-482. [CrossRef] [PubMed]

10. Kampschreur, M.J.; Temmink, H.; Kleerebezem, R.; Jetten, M.S.M.; van Loosdrecht, M.C.M. Nitrous oxide emission during wastewater treatment. Water Res. 2009, 43, 4093-4103. [CrossRef] [PubMed]

11. Melse, R.W.; Ploegaert, J.P.M.; Ogink, N.W.M. Biotrickling filter for the treatment of exhaust air from a pig rearing building: Ammonia removal performance and its fluctuations. Biosyst. Eng. 2012, 113, $242-252$. [CrossRef]

12. Dumont, E. Impact of the treatment of $\mathrm{NH}_{3}$ emissions from pig farms on greenhouse gas emissions. Quantitative assessment from the literature data. New Biotechnol. 2018, 46, 31-37. [CrossRef] [PubMed]

13. Roy, D.; Benkaraache, S.; Lemay, J.F.; Landry, D.; Drogui, P.; Tyagi, R.D. High-strength ammonium wastewater treatment by MBR: Steady-state nitrification kinetic parameters. J. Water Process. Eng. 2019, 32, 100945. [CrossRef]

14. Sander, R. Compilation of Henry's law constants (version 4.0) for water as solvent. Atmos. Chem. Phys. 2015, 15, 4399-4981. [CrossRef]

15. Hamon, L.; Andrès, Y.; Dumont, E. Aerial Pollutants in Swine Buildings: A Review of Their Characterization and Methods to Reduce Them. Environ. Sci. Technol. 2012, 46, 12287-12301. [CrossRef] [PubMed]

16. Blázquez, E.; Bezerra, T.; Lafuente, J.; Gabriel, D. Performance, limitations and microbial diversity of a biotrickling filter for the treatment of high loads of ammonia. Chem. Eng. J. 2017, 311, 91-99. [CrossRef]

17. Vaddella, V.; Ndegwa, P.; Jiang, A. An Empirical Model of Ammonium Ion Dissociation in Liquid Dairy Manure. Trans. ASABE 2011, 54, 1119-1126. [CrossRef]

18. Ottosen, L.D.M.; Juhler, S.; Guldberg, L.B.; Feilberg, A.; Revsbech, N.P.; Nielsen, L.P. Regulation of ammonia oxidation in biotrickling airfilters with high ammonium load. Chem. Eng. J. 2011, 167, 198-205. [CrossRef]

19. Vannecke, T.P.W.; Bernet, N.; Winkler, M.K.H.; Santa-Catalina, G.; Steyer, J.P.; Volcke, E.I.P. Influence of Process Dynamics on the Microbial Diversity in a Nitrifying Biofilm Reactor: Correlation Analysis and Simulation Study. Biotechnol. Bioeng. 2016, 113, 1962-1974. [CrossRef] [PubMed]

20. Anthonisen, A.C.; Loehr, R.C.; Prakasam, T.B.S.; Srinath, E.G. Inhibition of Nitrification by Ammonia and Nitrous Acid. J. Water Pollut. Control. Fed. 1976, 48, 835-852. [PubMed]

21. Clegg, S.L.; Brimblecombe, P. Solubility of ammonia in pure aqueous and multicomponent solutions. J. Phys. Chem. 1989, 93, 7237-7248. [CrossRef]

C 2020 by the authors. Licensee MDPI, Basel, Switzerland. This article is an open access article distributed under the terms and conditions of the Creative Commons Attribution (CC BY) license (http://creativecommons.org/licenses/by/4.0/). 